\title{
Results of a screening programme to identify plants or plant extracts that inhibit ruminal protein degradation
}

\author{
N. Selje ${ }^{1}$, E. M. Hoffmann ${ }^{1}$, S. Muetzel ${ }^{1}$, R. Ningrat ${ }^{2}$, R. J. Wallace ${ }^{2}$ and K. Becker ${ }^{1 *}$ \\ ${ }^{1}$ Department for Aquaculture Systems and Animal Nutrition, Institute for Animal Production in the Tropics and Subtropics, \\ University of Hohenheim, PO 109, D- 70593 Stuttgart, Germany \\ ${ }^{2}$ Rowett Research Institute, Greenburn Road, Bucksburn, Aberdeen AB21 9SB, UK
}

(Received 4 May 2006 - Revised 8 November 2006 - Accepted 9 November 2006)

One aim of the EC Framework V project, 'Rumen-up' (QLK5-CT-2001-00 992), was to find plants or plant extracts that would inhibit the nutritionally wasteful degradation of protein in the rumen. A total of 500 samples were screened in vitro using ${ }^{14} \mathrm{C}$-labelled casein in a 30 -min incubation with ruminal digesta. Eight were selected for further investigation using a batch fermentation system and soya protein and bovine serum albumin as proteolysis substrates; proteolysis was monitored over $12 \mathrm{~h}$ by the disappearance of soluble protein and the production of branched SCFA and $\mathrm{NH}_{3}$. Freeze-dried, ground foliage of Peltiphyllum peltatum, Helianthemum canum, Arbutus unedo, Arctostaphylos uva-ursi and Knautia arvensis inhibited proteolysis $(P<0 \cdot 05)$, while Daucus carota, Clematis vitalba and Erica arborea had little effect. Inhibition by the first four samples appeared to be caused by the formation of insoluble tannin-protein complexes. The samples were rich in phenolics and inhibition was reversed by polyethyleneglycol. In contrast, $K$. arvensis contained low concentrations of phenolics and no tannins, had no effect in the 30-min assay, yet inhibited the degradation rate of soluble protein (by $14 \%, P<0.0001$ ) and the production of branched SCFA (by $17 \%, P<0.05$ ) without precipitating protein in the 12 -h batch fermentation. The effects showed some resemblance to those obtained in parallel incubations containing $3 \mu \mathrm{M}$-monensin, suggesting that $K$. arvensis may be a plant-derived feed additive that can suppress growth and activity of key proteolytic ruminal micro-organisms in a manner similar to that already well known for monensin.

Knautia arvensis: Monensin: Proteolysis: Rumen

The efficient utilization of dietary protein is a key issue of ruminant nutrition. In the rumen, $70-80 \%$ of the protein is degraded via peptides and amino acids to ammonium and SCFA including branched chain fatty acids (Barry \& McNabb, 1999; National Research Council, 2001). On protein-rich diets used in intensive production systems, proteolysis by ruminal micro-organisms becomes a wasteful process, if dietary protein is broken down in excess of the requirements for maximal microbial growth and degradation of the feed (Leng \& Nolan, 1984). The amount of protein available to the ruminant depends on the combination of microbial protein reaching the small intestine and the amount of dietary protein that escapes microbial degradation (by-pass protein). To sustain high productivities, high-yielding dairy cows need large quantities of by-pass protein that can be hydrolysed and absorbed post-ruminally (Santos et al. 1998). Thus, the proportion of by-pass protein constitutes one of the major factors of feed $\mathrm{N}$ value (Michelet-Doreau \& Ould-Bah, 1992).

Ionophores have often been used as feed additives to increase feed conversion efficiency in ruminants. Part of the mode of action of ionophores involves improved protein utilization, which results from effects on ruminal protein metabolism. The ionophores, monensin, salinomycin and tetronasin, have protein-sparing effects that are mediated by decreased breakdown of protein, peptides and amino acids (Van Nevel \& Demeyer, 1977; Newbold et al. 1990; Yang \& Russell, 1993; McAllister et al. 1994). The ban of growth-promoting antimicrobials by the European Union in 2006 means that additives such as ionophores can no longer be used in Europe, which highlights the need for alternative ways to promote efficient $\mathrm{N}$ utilization in ruminants. Plants or plant-derived products offer a promising alternative (Wallace, 2004).

Studies of plants and phytochemicals that inhibit ruminal proteolysis have generally involved tannin-containing extracts or tannin-rich plants (McMahon et al. 2000; Hervás et al. 2004; Martínez et al. 2004). By forming complexes with proteins, tannins decrease the availability of soluble protein to proteases and thus decrease proteolysis (Tanner et al. 1994). In vivo studies have shown that tannins from various sources led to decreased ruminal $\mathrm{NH}_{3}$ concentrations and an enhanced non- $\mathrm{NH}_{3}-\mathrm{N}$ flow to the duodenum in sheep (Hervás et al. 2000; Śliwiński et al. 2002). However, tannins cause adverse effects such as decreased feed intake (Silanikove et al. 2001),

Abbreviations: BSA, bovine serum albumin; PEG, polyethylene glycol.

* Corresponding author: Professor Klaus Becker, fax +49 711 45923702, email kbecker@uni-hohenheim.de 
a decline in fibre digestibility (McAllister et al. 1994; Barry \& McNabb, 1999; Hervás et al. 2003) and a decrease in post-ruminal degradation of protein (Hervás et al. 2000). Saponins and saponin-containing plants also improve protein flow from the rumen, but this appears to be mediated mainly by suppressing ciliate protozoa (Wina et al. 2005).

The EC project, 'Rumen-up' (QLK5-CT-2001-00 992, http://www.rowett.ac.uk/rumen_up/), was commissioned in order to explore plant-based alternatives to antimicrobial growth promoters in ruminants. One of its aims was to find plants or their extracts that decrease ruminal proteolysis. Here we report the findings of the screening programme. The results demonstrate that, although most samples that inhibited proteolysis did so via their tannin content, Knautia arvensis (field scabious) inhibited proteolysis by a different mechanism, which was more readily detected in vitro in growing batch cultures rather than by direct measurement of the proteolytic activity of digesta.

\section{Materials and methods}

\section{Plant samples}

Plant samples were derived from the 'Rumen-Up' collection. The collection comprised 450 samples of plant parts, the great majority consisting predominantly of foliage, and fifty essential oil compounds. The species and compounds comprising the collection can be found online (http://www.rowett.ac. uk/rumen_up/). After collection, plants were freeze-dried, ground to pass through a $1 \mathrm{~mm}$ sieve and stored in glass jars in the dark.

\section{Animals, diets and preparation of ruminal digesta}

Three ruminally cannulated adult sheep received a maintenance diet comprising grass hay, rolled barley, cane molasses, fish meal and minerals and vitamins (Lamscov Intensive Lamb 317; Norvite, Insch, Aberdeenshire, UK) at concentrations of 500, 299.5, 100, 91 and $9.5 \mathrm{~g} / \mathrm{kg} \mathrm{DM}$, respectively, fed in equal meals of $500 \mathrm{~g}$ at 08.00 and 16.00 hours. Samples of ruminal fluid were removed $2 \mathrm{~h}$ after the morning feeding and strained through two layers of muslin cloth before use in experimental measurements.

Five ruminally cannulated lactating Holstein cows received a total mixed ration fed ad libitum $(18-19 \mathrm{~kg})$ in two equal meals at 08.00 and 16.00 hours. The ration contained legume seeds (Lupinus angustifolius), maize silage, hay, maize kernel, grass silage, wheat and minerals at concentrations of $300,274,140,132,83,44,27 \mathrm{~g} / \mathrm{kg}$ DM. Contents of organic matter, crude protein, crude fibre and metabolizable energy were 926, 163, $184 \mathrm{~g}$ and $11.4 \mathrm{MJ}$ per kg DM. Ruminal digesta was collected prior to morning feeding. Liquid digesta was prepared by manually pressing out liquid from the feed mat into preheated thermos flasks. The fluid was filtered through a $100 \mu \mathrm{m}$ nylon net and diluted 1:10 with pre-warmed reduced buffer medium $(13.5 \mathrm{~mm}$ $\mathrm{NH}_{4}\left(\mathrm{CO}_{3}\right)_{2}, 86.5 \mathrm{~mm}-\mathrm{Na}\left(\mathrm{CO}_{3}\right)_{2}, \quad 5.5 \mathrm{~mm}-\mathrm{Na}_{2} \mathrm{HPO}_{3}, 9.5 \mathrm{~mm}-$ $\mathrm{KH}_{2} \mathrm{PO}_{3}, \quad 0.5 \mathrm{~mm}-\mathrm{MgSO}_{4} .7 \times \mathrm{H}_{2} \mathrm{O}, \quad 0.020 \%$ microminerals $\left(0.45 \mathrm{M}-\mathrm{CaCl}_{2}, \quad 0.25 \mathrm{M}-\mathrm{MnCl}_{4}, \quad 0.02 \mathrm{M}-\mathrm{CoCl}_{6}, 0.15 \mathrm{M}-\right.$ $\left.\mathrm{Fe}(\mathrm{Cl})_{3}\right), 6 \%$ reducing solution $(0.118$ M-cysteine $\mathrm{HCl}$, $\left.0.04 \% 1 \mathrm{M}-\mathrm{NaOH}, 0.026 \mathrm{~N} \mathrm{Na}_{2} \mathrm{~S}\right), 0.001 \%$ resazurin).

\section{Screening for effects on proteolytic activity}

The effects of all 500 samples on rumen microbial proteolytic activity were investigated using casein (Sigma Chemical Co, Poole, Dorset, UK) reductively methylated with $\left[{ }^{3} \mathrm{H}\right]$ or $\left[{ }^{14} \mathrm{C}\right]$ formaldehyde (Wallace, 1983) as substrate and ruminal digesta obtained from the sheep. The assay contained $1.0 \mathrm{ml}$ strained ruminal fluid, to which was added $3.0 \mathrm{ml}$ anaerobic $50 \mathrm{~mm}$-potassium phosphate buffer, $\mathrm{pH} \mathrm{7.0,} \mathrm{containing} 4 \mathrm{mg}$ ${ }^{14} \mathrm{C}$-labelled casein $/ \mathrm{ml}$. Ground sample was added to the incubation mixture to give a final concentration of $1 \mathrm{~g} / \mathrm{l}$. Essential oils were added in ethanolic solution, to final concentrations of $100 \mathrm{ppm}$. After $30 \mathrm{~min}$ incubation at $39^{\circ} \mathrm{C}$, the reaction was stopped by the addition of $1 \mathrm{ml} 25 \%$ TCA. Samples were chilled at $4^{\circ} \mathrm{C}$ and then centrifuged at $13000 \mathrm{~g}$ for $5 \mathrm{~min}$. Incubations were carried out in duplicate. Acid-soluble ${ }^{14} \mathrm{C}$ in the supernatant fluid was measured by liquid-scintillation spectrometry. The results were analysed by ANOVA using Genstat 6 software (VSN International Ltd., Hemel Hempstead, UK).

\section{Protein degradation studies using batch culture}

A batch culture method was adopted that was based on the method developed by Mauricio et al. (1999). Incubations were run in $125 \mathrm{ml}$ serum flasks at $39^{\circ} \mathrm{C}$ under $\mathrm{CO}_{2}$. Of the buffered bovine digesta $75 \mathrm{ml}$ was added to pre-warmed flasks containing a substrate mix consisting of $450 \mathrm{mg}$ maize silage and $225 \mathrm{mg}$ barley grain ground to $1 \mathrm{~mm}$. Bovine serum albumin (BSA; A9647, Sigma-Aldrich Chemie GmbH, Schnelldorf, Germany; protein content $\geq 96 \%$ ) and soyabean flour (S9633; protein content approximately 52\%) were added to final concentrations of 0.13 and $2.0 \mathrm{~g} / \mathrm{l}$, respectively. Crude nutrients (Association of Official Analytical Chemists, 1990) and fibre contents (Van Soest et al. 1991) of the single substrates and of the final mixture are given in Table 1. Plants

Table 1. Crude nutrient and fibre contents of major substrate components and of the final mixture used in the batch-culture system ${ }^{\star}$

\begin{tabular}{|c|c|c|c|c|c|c|c|}
\hline & $\begin{array}{c}\mathrm{DM} \\
\text { (\% fresh matter) }\end{array}$ & $\begin{array}{c}\text { Ash } \\
\text { (\% DM) }\end{array}$ & $\begin{array}{l}\text { Crude protein } \\
\text { (\% DM) }\end{array}$ & $\begin{array}{l}\text { Ether extract } \\
\text { (\% DM) }\end{array}$ & $\begin{array}{l}\text { Neutral-detergent } \\
\text { fibre (\% DM) }\end{array}$ & $\begin{array}{l}\text { Acid-detergent } \\
\text { fibre (\% DM) }\end{array}$ & $\begin{array}{l}\text { Acid-detergent } \\
\text { lignin (\% DM) }\end{array}$ \\
\hline Maize silage & $92 \cdot 0$ & $4 \cdot 1$ & $7 \cdot 0$ & 2.7 & 38.9 & 30.5 & $3 \cdot 8$ \\
\hline Barley grain & 89.5 & $2 \cdot 0$ & $9 \cdot 8$ & $1 \cdot 7$ & 32.9 & 7.0 & 1.5 \\
\hline Soyabean flour & $95 \cdot 0$ & $6 \cdot 2$ & 52.9 & 0.6 & $6 \cdot 7$ & $26 \cdot 2$ & 0.1 \\
\hline Substrate mix & $91 \cdot 1$ & 3.9 & $16 \cdot 9$ & 1.9 & $31 \cdot 3$ & $23 \cdot 1$ & 3.5 \\
\hline
\end{tabular}

${ }^{*}$ Final substrate mix contained (mg): maize silage 450; barley grain 225; soyabean flour 150; bovine serum albumin 10.

$\dagger$ For details of diets and procedures, see Materials and methods. 
were added at an inclusion level of $18 \%(w / w)$ of total substrate, replacing the corresponding amount of maize silage. To estimate the impact of tannins present in plant samples, parallel incubations were performed in the presence of $6 \mathrm{~g} / \mathrm{l}$ polyethylene glycol (PEG) (PEG-6000; Merck, Darmstadt, Germany). Three flasks containing buffered rumen fluid served as blanks to correct for gas release and fermentation products originating from the inoculum. Three flasks containing buffered rumen fluid and basic substrate plus respective protein supplement served as controls. Three parallels were inoculated per treatment with one replicate being reserved for gas readings up to $12 \mathrm{~h}$ of incubation. Aliquots $(1 \mathrm{ml})$ were withdrawn from the remaining two replicates periodically under vigorous stirring and centrifuged immediately $\left(30000 \mathrm{~g}, 10 \mathrm{~min}, 4^{\circ} \mathrm{C}\right)$. The pellet and $50 \mu \mathrm{l}$ supernatant were used for analysis of the protein fractions. To the remaining supernatant $(630 \mu \mathrm{l}), 70 \mu \mathrm{l}$ formic acid containing an internal standard (1\% methylbutryric acid) was added and proteins were precipitated overnight at $4^{\circ} \mathrm{C}$. Samples were centrifuged $\left(30000 \mathrm{~g}, 10 \mathrm{~min}, 4^{\circ} \mathrm{C}\right)$ and the supernatant was collected for analysis of SCFA and $\mathrm{NH}_{3}$.

Incubations with monensin (Sigma-M5273) served as standard in all experiments. A stock solution in ethanol was prepared freshly before incubations and $11.25 \mu$ l was dosed into each flask immediately after filling. The resulting ethanol concentration was shown to have no measurable effects on fermentation. The final concentration $(3 \mu \mathrm{M})$ chosen lay at the lower end of concentrations of $3-9 \mu \mathrm{M}$ commonly used in in vivo studies (Callaway et al. 1997; Ramanzin et al. 1997; Phipps et al. 2000).

\section{Biochemical analyses}

Concentrations of SCFA were determined by GC using a stainless steel column packed with GP $10 \%$ SP $10001 \%$ $\mathrm{H}_{3} \mathrm{PO}_{4}$, Chromosob WAW (Supelco Inc., Bellafonte, PA, USA) (Hoeltershinken et al. 1997). $\mathrm{NH}_{3}$ concentration was measured by the phenol-hypochlorite method (Koroleff, 1976) adapted to microtitre plate dimensions. Soluble protein was determined by dot blot directly from the supernatant as described in Hoffmann et al. (2002). Pellets were solubilized in denaturing buffer (Laemmli, 1970) before blotting to determine insoluble protein. Total protein was calculated from the sum of the two protein fractions. Individual protein bands were quantified after separation by SDS-PAGE (Laemmli, 1970). Samples of $6 \mu \mathrm{l}(0.5-2.0 \mathrm{~g} / \mathrm{l}$ protein) were loaded on discontinuous polyacrylamide gels (Hoefer system 'mighty small II') with $15 \%$ acrylamide in the separating gel. Gels were run for $60 \mathrm{~min}(10 \mathrm{~min}$ at $25 \mathrm{~mA}, 50 \mathrm{~min}$ at $40 \mathrm{~mA})$, fixed in $10 \%$ sulfosalicylic acid for $30 \mathrm{~min}$ and stained with Coomassie Brilliant Blue (Neuhoff et al. 1985). Broad range markers (1610317; Bio-Rad Laboratories GmbH, Munich, Germany) were used as molecular weight standards. Gels were documented with a digital camera system (DIANA 1.6; Raytest GmbH, Straubenhardt, Germany) and representative protein bands were quantified by image analysis (AIDA 2.31; Raytest).

For tannin analyses, freeze-dried plant samples were ground to a fine powder and tannins were extracted in $50 \%(\mathrm{v} / \mathrm{v})$ aqueous methanol (Makkar et al. 1988a). Total phenols and total precipitable phenolics ('total tannins') were determined by the ferric chloride assay using the entire extract, or after tannin-protein precipitation with BSA solution $(2 \mathrm{~g} / \mathrm{l})$, respectively (Hagerman \& Butler, 1978).

\section{Statistical analyses and calculation of protein degradation rates}

Results obtained from batch incubations were analysed for effects of additives, of plant samples as well as of monensin, on fermentation parameters using a general linear model (SAS V9.1; SAS Institute Inc, Cary, NC, USA). Degradation of soluble protein followed a linear regression (mean coefficient $r^{2} 0.918, n$ 20). Thus, protein degradation rates $\left(k_{\mathrm{d}}\right)$ were calculated from protein concentrations (B) at individual sampling times $(t)$ or from regression curves over entire incubation according to the formula:

$$
k_{\mathrm{d}}\left[h^{-1}\right]=\left(B_{t 1}-B_{t 2}\right) / B_{t 1} /\left(t_{2}-t_{1}\right) .
$$

Fraction $\mathrm{B}$ was set to $100 \%$ assuming that soluble protein is fully degradable.

\section{Results}

\section{Screening of 500 samples for inhibition of proteolysis}

Plant samples were derived from the 'Rumen-Up' collection, which comprised 450 samples of plant parts and fifty essential oil compounds. The entire collection was screened for effects on general fermentation parameters (not shown) to omit samples negatively influencing digestibility.

The samples were screened for their effects on proteolysis at a concentration of $1 \mathrm{~g} / \mathrm{l}$ using a 30-min assay based on the digestion of radiolabelled casein. Subsequently, twenty-one samples testing positive initially for inhibitory activity were tested further in a 12-h batch culture system containing a $10 \%$ inoculum. A short list of promising samples was drawn up to be investigated in more detail. Four samples, Helianthemum canum, Erica arborea, Arbutus unedo and Arctostaphylos uva-ursi, were chosen because of their inhibition of ${ }^{14} \mathrm{C}$-labelled casein degradation. Four additional samples, Daucus carota, Clematis vitalba, Knautia arvensis and Peltiphyllum peltatum, were chosen because they caused decreased $\mathrm{NH}_{3}$ and/or branched SCFA concentrations in the batch culture. The origins, common names and further details of the selected samples are given in Table 2 .

\section{Influence of selected samples on digestion of protein and fermentation in vitro}

The selected samples were added to the batch culture system at an inclusion level of $18 \%(\mathrm{w} / \mathrm{w})$ total substrate, replacing the corresponding amount of maize silage. Incubations were run for $12 \mathrm{~h}$; since previous runs had shown that maximal fermentation rate (determined by maximal gas production rate) was reached after $4-6 \mathrm{~h}$ (in $82 \%$ of seventeen independent incubations, mean $4.6 \mathrm{~h}$, earliest after $3 \mathrm{~h}$, latest after $8 \mathrm{~h}$ ) and declined afterwards. After disappearance of soluble substrate protein, soluble protein concentration rose again after $12-15 \mathrm{~h}$, most probably due to autolysis of micro-organisms.

From repeated independent incubations, the effects of the plant additives and of monensin were assessed as a percentage of values obtained in control flasks at the respective sampling 
Table 2. Description of plant samples selected for detailed screening*

\begin{tabular}{|c|c|c|c|c|c|c|}
\hline Scientific name & Common name & Family & Fraction harvested & Vegetative state & Date of harvest & Origin \\
\hline Helianthemum canum & Hoary rockrose & Cistaceae & leaves, flowers & early flowering & 1 June 2001 & Sobarriba, Spain \\
\hline Erica arborea & Tree heather & Ericaceae & leaves, flowers & early flowering & 1 June 2001 & Sobarriba, Spain \\
\hline Knautia arvensis & Field scabious & Dipsacaceae & whole over ground & early fruiting & 5 June 2001 & Las Salas, Spain \\
\hline Daucus carota & Wild carrot & Umbelliferae & whole over ground & not flowering & 7 June 2001 & Mansilla Mayor, Spain \\
\hline Clematis vitalba & Old Man's Beard & Ranunculaceae & shoots & flowering & 13 August 2002 & Hohenheim, Germany \\
\hline Arbutus unedo & Strawberry tree & Ericaceae & leaves, stem & NS & 27 August 2002 & Aberdeen, UK \\
\hline Arctostaphylos uva-ursi & Bearberry & Ericaceae & leaves, stem & NS & 7 September 2001 & Bennachie, UK \\
\hline Peltiphyllum peltatum & Indian rhubarb & Saxifragaceae & leaves, stem & NS & 27 September 2002 & Aberdeen, UK \\
\hline
\end{tabular}

${ }^{*}$ For details of procedures, see Materials and methods. NS, not specified.

times, with a $3 \mu \mathrm{M}$-monensin treatment included as a positive, i.e. inhibitory, reference material (Table 3). Neither any of the eight plant samples nor $3 \mu \mathrm{M}$-monensin showed a significant impact on SCFA production, indicating that carbohydrate fermentation was not negatively influenced. Five samples proved to have significant effects on protein degradation. $P$. peltatum, $H$. canum, $A$. unedo and $A$. uva-ursi strongly decreased the concentration of $\mathrm{NH}_{3}$ and branched SCFA. The effects of $P$. peltatum and $H$. canum on branched SCFA production were particularly marked, causing $>70 \%$ inhibition. With $P$. peltatum, H. canum, $A$. unedo and $A$. uva-ursi, insoluble protein concentration after $12 \mathrm{~h}$ of incubation tended to be higher than in the control, with the effect reaching significance $(P<0 \cdot 05)$ for $P$. peltatum, H. canum and A. uva-ursi. K. arvensis addition led to a decreased concentration of branched SCFA but not $\mathrm{NH}_{3}$ at $12 \mathrm{~h}$. The mechanism whereby $K$. arvensis caused the inhibition was apparently different to the other four samples, in that $K$. arvensis increased the final concentration of soluble, but not insoluble, protein after $12 \mathrm{~h}$ incubation, whereas the others caused a small decrease in soluble protein concentration and an increase in insoluble protein. The others also caused $8-18 \%$ decreases in gas production, while $K$. arvensis did not inhibit gas production. Only minor effects on the major SCFA were observed with the plant samples. The effects of $K$. arvensis resembled those of monensin in decreasing soluble protein degradation and branched SCFA production, but differed in that $K$. arvensis did not decrease $\mathrm{NH}_{3}$ formation, the $\mathrm{C} 2$ : $\mathrm{C} 3$ ratio or gas production. Degradation rates of soluble protein in controls, monensin and $K$. arvensis flasks were significantly different $(P=0.0001)$ amounting to $0.085,0.039$ and 0.068 per $\mathrm{h}$ after $9 \mathrm{~h}$, and $0.071,0.061$ and 0.040 per $\mathrm{h}$ when calculated from the slope of protein kinetics.

\section{Assessment of mechanisms of inhibition}

The effects of $P$. peltatum, H. canum, A. unedo and A. uva-ursi were similar, characterized by decreases in soluble protein concentration and larger increases in insoluble protein remaining, with the end products of proteolysis being decreased. Protein precipitation by $P$. peltatum, and the corresponding absence of precipitation by $K$. arvensis, was illustrated by SDS-PAGE (Fig. 1). When $K$. arvensis was added, the substrate protein remained soluble and was degraded over time, as demonstrated by the fading of the protein bands after 6 and $12 \mathrm{~h}$, in particular of the two major soya bands (Fig. 1(C)). When P. peltatum was added, apart from a faint BSA band substrate protein was not detected in the soluble fraction, but appeared in the pellet fraction and the decrease of band intensities over time was less pronounced. After $12 \mathrm{~h}$ incubation, soya protein band 2 was still clearly visible (Fig. 1(D)). The percentage of protein precipitated was highest at the beginning of the incubation, when soluble protein concentration in the control was highest.

The influence of samples on proteolytic activity in short incubations of ruminal digesta with ${ }^{14} \mathrm{C}$-labelled casein indicated that there was no immediate effect of $K$. arvensis (Table 4). P. peltatum, H. canum, E. arborea, A. unedo and A. uva-ursi

Table 3. Relative values of fermentation parameters in 12-h batch-culture incubations with eight plant materials and $3 \mu \mathrm{M}-\mathrm{monensin} \ddagger$

\begin{tabular}{|c|c|c|c|c|c|c|c|}
\hline Treatment & Soluble protein & Insoluble protein & Branched SCFA & $\mathrm{NH}_{3}$ & SCFA & $\mathrm{C} 2 / \mathrm{C} 3$ & Gas \\
\hline Control & 100 & 100 & 100 & 100 & 100 & 100 & 100 \\
\hline Monensin & $261^{\star * *}$ & 87 & $61^{\star * *}$ & $89^{*}$ & 98 & $70^{\star \star \star}$ & $90^{* *}$ \\
\hline Knautia arvensis & $161^{\star \star}$ & 98 & $83^{\star}$ & 97 & 115 & 97 & 100 \\
\hline Daucus carota & 109 & 117 & 101 & 104 & 120 & 104 & 103 \\
\hline Clematis vitalba & 104 & 100 & 92 & 98 & 112 & 97 & $95^{+}$ \\
\hline Erica arborea & 81 & 107 & $87 \dagger$ & 91 & 107 & $108^{*}$ & $88^{\star \star *}$ \\
\hline Peltiphyllum peltatum & 79 & $158^{* *}$ & $27^{\star \star \star}$ & $60^{\star \star \star}$ & 97 & 105 & $83^{\star \star \star}$ \\
\hline Helianthemum canum & 88 & $167^{\star *}$ & $29^{\star \star \star}$ & $68^{\star \star \star}$ & 95 & 108 & $82^{\star \star \star}$ \\
\hline Arctostaphylos uva-ursi & 88 & $142^{*}$ & $78^{* *}$ & $82^{\star *}$ & 107 & $107^{+}$ & $92^{\star}$ \\
\hline Arbutus unedo & 94 & $134^{+}$ & $74^{\star \star \star}$ & $86^{* *}$ & 105 & $109^{\star}$ & $88^{\star \star \star}$ \\
\hline SEM & $15 \cdot 7$ & 15.9 & $5 \cdot 6$ & 3.9 & 13.4 & 2.9 & $2 \cdot 3$ \\
\hline$P>F$ & $<0.0001$ & 0.0032 & $<0.0001$ & $<0.0001$ & 0.868 & $<0.0001$ & $<0.0001$ \\
\hline
\end{tabular}

All values are concentrations relative to concentrations in control incubations 100 , except gas production, which is expressed as ml/g substrate with the control value 100. Values are means of four independent runs with different rumen inocula, except for $E$. arborea, $H$. canum and $A$. uva-ursi (three independent runs). Mean values were significantly different from control; ${ }^{\star} P<0.05 ;{ }^{\star \star} P<0.01 ;{ }^{\star \star \star} P<0.001 ; \dagger P<0.09$.

‡For details of procedures, see Materials and methods. 
(A)

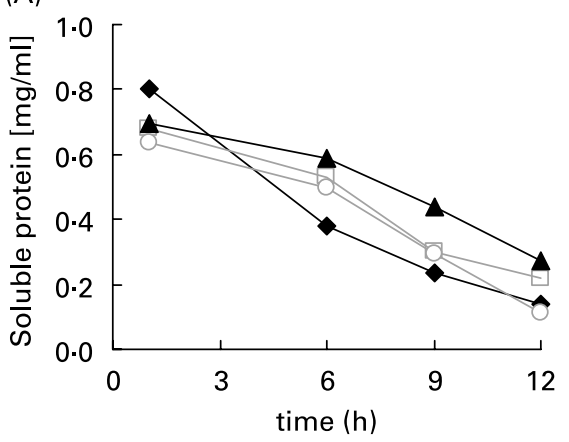

(C)

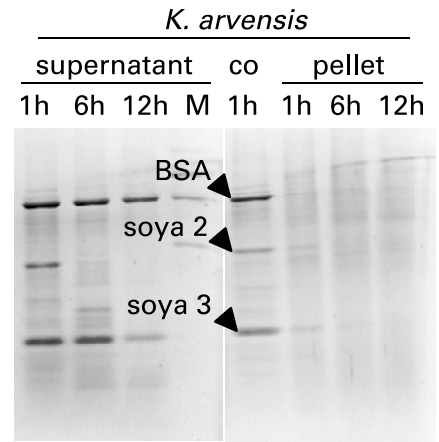

(B)

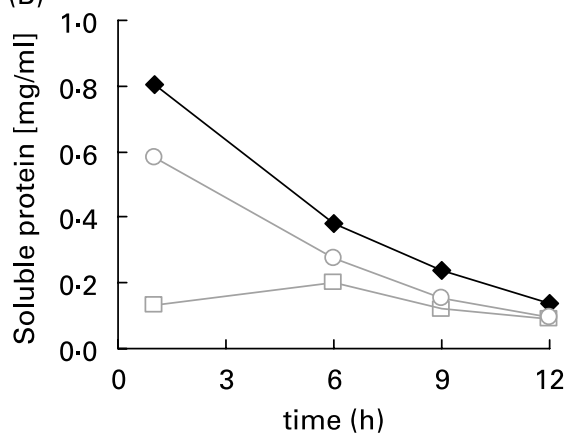

(D)

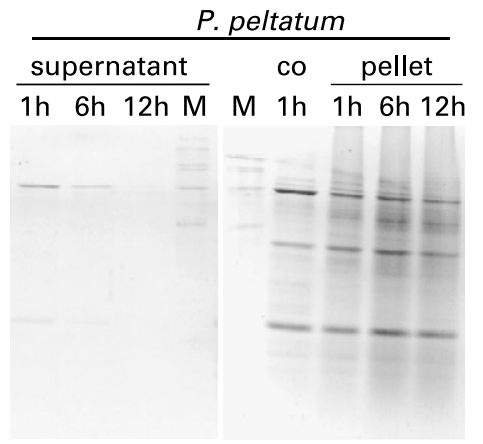

Fig. 1. Kinetics of soluble protein concentration in batch-culture incubations with Knautia arvensis and Peltiphyllum peltatum with and without the addition of polyethylene glycol (PEG). Protein degradation was determined by dot blot analysis and PAGE protein banding patterns of soluble and insoluble protein. (A) Kinetics of control

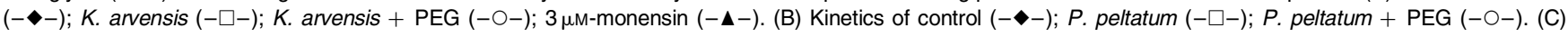
Banding patterns of supernatant and pellet subsamples after 1, 6 and $12 \mathrm{~h}$ incubation with $K$. arvensis. (D) Banding patterns of supernatant and pellet subsamples after 1,6 and $12 \mathrm{~h}$ incubation with $P$. peltatum. BSA, bovine serum albumin. For details of procedures, see Results.

gave inhibition that ranged from 9-28\%. Precipitation of soluble protein in the batch culture system was evident after $1 \mathrm{~h}$ with P. peltatum, H. canum, A. unedo, A. uva-ursi and E. arborea, ranging from $18-61 \%$ of control values (Table 4). Chemical analysis revealed high concentrations of phenolic compounds in five plants, namely, P. peltatum, H. canum, E. arborea, A. unedo and A. uva-ursi (Table 4). Concentrations of tannins followed a similar pattern. $K$. arvensis had a low content of total phenolic compounds and no detectable tannins. The ability of the plant samples to precipitate BSA corresponded to their tannin content with a correlation coefficient $r^{2} 0 \cdot 60$. The low correlation was due to $E$. arborea, which exhibits a high BSA precipitating activity; when E. arborea was excluded from the correlation, the coefficient between BSA precipitation and total tannins was $r^{2}$ 0.98. Total tannins were negatively correlated, with the percentage of mixed substrate protein remaining soluble after $1 \mathrm{~h}$ batchculture incubation, $r^{2} 0 \cdot 84$, and for the proteolytic activity measured by the ${ }^{14} \mathrm{C}$-method, $r^{2} 0 \cdot 80$. Further, total tannin content was negatively correlated with concentrations of end products after $12 \mathrm{~h}$ in batch cultures, $r^{2} 0.82$ with branched SCFA and $r^{2}$ 0.86 with $\mathrm{NH}_{3}$ concentration. Protein precipitation by $P$. peltatum, $H$. canum, A. uva-ursi, A. unedo and E. arborea was partly reversed by the addition of PEG (Table 4). While soluble protein concentrations in controls and with $K$. arvensis were not affected, PEG increased the concentration of soluble protein in P. peltatum flasks, particularly at $1 \mathrm{~h}$ (Fig. 1). Consequently, the inhibition of end-product formation of proteolysis mediated by $P$. peltatum, H. canum, A. uva-ursi, A. unedo and E. arborea was prevented, at least partially, by the addition of PEG (Table 4) leading to increased concentrations of branched SCFA and $\mathrm{NH}_{3}$ after $12 \mathrm{~h}$.

\section{Discussion}

The 'Rumen-up' collection of plants and plant extracts consists of 450 samples of plant material, mainly foliage, and fifty essential oil compounds. Broadly speaking, the samples were considered to be possible candidates for manipulating ruminal fermentation based on traditional uses, known phytochemical composition, agronomic properties and combinations of these factors. The collection was restricted to plants that grew or could be grown in one of the countries of the European Union. Thus, although a wide range of plant types was collected, the collection cannot be considered in any way to be representative of botanical diversity. Specimens were taken from different geographical locations, under different weather conditions and at different times of the year. Phytochemical concentrations in plant tissues are subject to change by all these factors (Wink, 1999). For example, the formation of steroidal saponins varied 13-14-fold in different samples of Narthecium ossifragum depending on location and time (Flåøyen et al. 2004). Furthermore, sample processing consisted of freeze-drying and storage for, in some cases, many months, which would influence the survival of volatile or labile compounds. Therefore, many possible positive samples could have been overlooked because they were collected at the wrong place or time, or were processed in an inappropriate way. Nevertheless, the results of the screening programme are indicative of the potential value of plants and their extracts as modifiers of ruminal fermentation.

The initial screening for samples inhibitory to ruminal proteolysis used a 30-min incubation of ruminal digesta with 


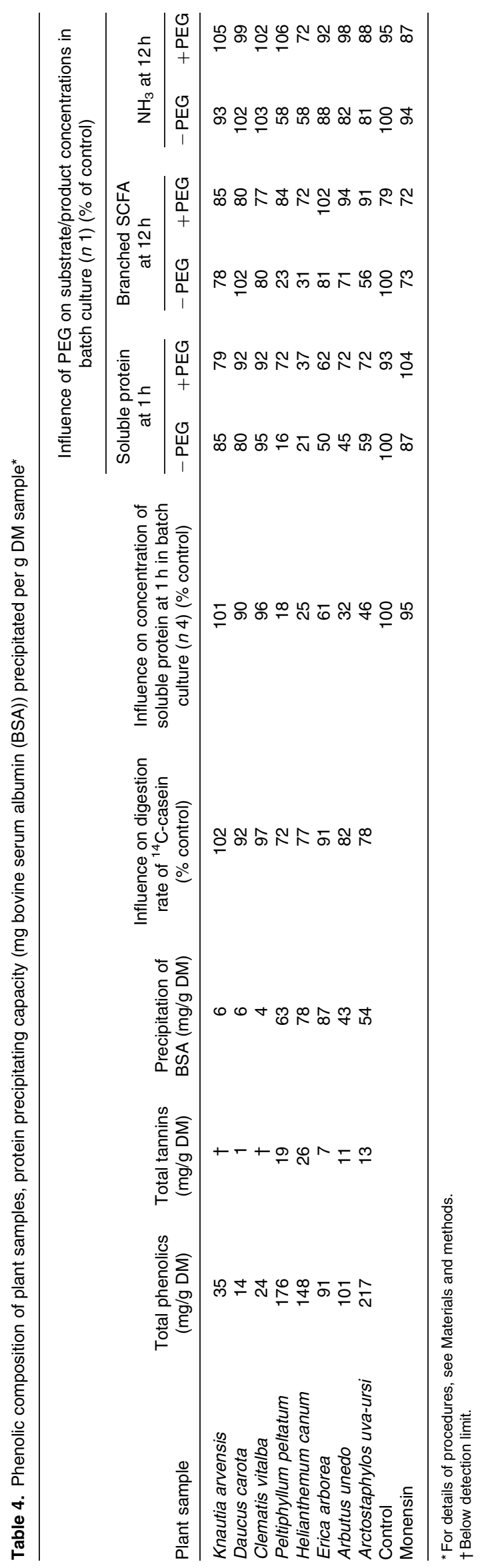

radiolabelled casein. No substrate was added that would support microbial growth. The assay was therefore a simple short-term determination of enzyme activity. Subsequently, an adaptation of the batch culture system developed by Mauricio et al. (1999) was used to investigate the most promising samples. The addition of BSA and soya proteins at the concentrations used here was the culmination of development work that established the most appropriate incubation times, proteins to add and the concentrations of the proteins to be added. A mixture of $2 \mathrm{mg} / \mathrm{ml}$ soyabean flour and $0.13 \mathrm{mg} / \mathrm{ml}$ BSA was chosen as protein supplement leading to a final crude protein content of $169 \mathrm{~g} / \mathrm{kg}$ in the substrate (Table 1), which is well within the range of practical diets. These concentrations further allowed complete degradation of soluble protein within 9-16h. Both protein sources yielded identifiable banding patterns for qualitative and quantitative analysis by PAGE. The most significant difference with the batch culture system was that it had the considerable advantage that microbial growth was a component of the incubation. Thus, samples that decreased proteolytic activity by suppressing the growth of certain bacteria involved in protein degradation, in a manner similar to the feedlot ionophore, monensin, (Yang \& Russell, 1993) could be identified. The batch culture system also enabled measurements of protein breakdown products, including branched SCFA and $\mathrm{NH}_{3}$. This capability reinforced direct measurements of proteolysis but also produced additional information about possible effects on deamination of amino acids.

Five of the samples identified in the initial screening programme retained their activity in the batch culture system. These samples, P. peltatum, H. canum, E. arborea, A. unedo and $A$. uva-ursi, were characterized by a high content of phenolic compounds in general and high biological protein precipitating capacities. Their tannin content and specific protein precipitating capacity varied, but the total tannin concentration corresponded reasonably well to the extent of inhibition of proteolysis in batch culture. Furthermore, the reversal of inhibition by PEG indicated that tannins were responsible for the inhibition. Tannins have long been known to inhibit protein digestion. Conversion of protein to an insoluble form less susceptible to proteinase activity is generally considered to be the mechanism by which they work (Molan et al. 2001). However, the present study illustrates that the ability to precipitate the model protein BSA is alone not sufficient to ensure effectiveness with other protein sources in a mixed incubation. E. arborea was most effective of all samples in precipitating BSA, but had a minor influence on proteolysis as determined by two independent methods using casein or soya meal as protein sources. It is possible that, in the protein-tannin complex formed, the protein remained susceptible to microbial digestion. Alternatively, the precipitating material may have been labile to microbial digestion. Nevertheless, tannins are highly heterogeneous in structure and the interaction of different tannins with protein may yield complexes that vary in their protection in the rumen and subsequent ability to release the protein in the small intestine. Their effectiveness nutritionally may therefore differ in a similar manner. The use of tannin-rich feeds, although promising in some trials, has often not yielded the anticipated nutritional benefits in in vivo trials (Waghorn et al. 1987; Barry \& McNabb, 1999, Poncet \& Rémond, 2002). Increased abomasal protein flows 
induced by Lotus pedunculatus were counteracted by a decreased apparent digestibility in the small intestine, resulting in only a small increase in apparent absorption of essential amino acids (Waghorn et al. 1994). These results were attributed to either the tannins not releasing amino acids in the small intestine or to their inactivating digestive enzymes. One of the greatest problems with tannins is that they interact with microbial enzymes as well as feed proteins, resulting in decreased fermentative activity (Reed et al. 1982; Makkar et al. 1988b). The tannin-rich samples investigated here all gave decreased gas production over $12 \mathrm{~h}$. SCFA production was unaffected, however, so the samples appear to merit further investigation as potential feed additives.

$K$. arvensis had entirely different properties. The inhibition of proteolysis was not mediated by tannins, since the tannin content of the plant sample was very low and the effect was not reversible by the addition of PEG. Several components of plant tissues other than tannins are known to inhibit proteolysis. Some inhibitors, such as soyabean trypsin inhibitor, are polypeptides (Beynon \& Salvesen, 1989). Others are enzymes that release inhibitory compounds. Polyphenol oxidase converts phenols into quinones, which then react rapidly with proteins or proteolytic enzymes, an activity that leads to decreased degradation rates of substrate protein. This activity causes improvements in protein survival during the ensiling of red clover in comparison to alfalfa and other clover species (Jones et al. 1995) and a greater rumen escape was estimated for red clover proteins (Broderick \& Albrecht, 1997). The agent in K. arvensis responsible for decreasing proteolysis seems unlikely to be polypeptide in nature, however, because activity was retained following treatment of the plant material with hot petroleum ether at $90^{\circ} \mathrm{C}$ (N. Selje, E. M. Hoffman \& K. Becker, unpublished results). Saponins also improve $\mathrm{N}$ retention by intervening in microbial proteolytic activity. It is not a direct effect on proteolysis, however, but a suppression of the bacteriolytic activity of protozoa (Eugène et al. 2004). Few reports exist on the proteinbinding capacities of saponins and effects on enzyme activities that seem highly dependent on the quality of saponins and proteins (Potter et al. 1993, Ikedo et al. 1996, Shimoyamada et al. 1998). In continuous culture, extracts of yucca (8\% sarsaponin) led to an accumulation of peptide-N, which was attributed to either a stimulation of proteolysis or an inhibition of peptidolysis (Cardozo et al. 2004).

The active ingredient in $K$. arvensis appears more likely to be a selective inhibitor of bacterial growth rather than a protease inhibitor. In some ways, the effect resembled that of monensin. The effects of monensin in the batch culture system were similar to those described from other in vitro and in vivo studies (Van Nevel \& Demeyer, 1977; Schelling, 1984; Jalč \& Lauková, 2002). The greatest effect of monensin was a decreased degradation of soluble protein, which was accompanied by a decrease in the concentration of end products, in particular of branched SCFA. Monensin is an ionophore that selectively inhibits the growth of Gram-positive bacteria (Chen \& Wolin, 1979) and leads to adaptive changes in some Gram-negative species (Callaway \& Russell, 1999), both of which contribute to a slowing of $\mathrm{NH}_{3}$ formation from protein. Some phytochemicals may have similar effects. McIntosh et al. (2003) reported on the inhibitory effects of an essential oil preparation on deamination of amino acids in ruminal digesta in vitro, an effect that was attributed to a selective inhibition of obligately peptidolytic Gram-positive species, Clostridium, Peptostreptococcus and Eubacterium. Preliminary analysis by HPLC indicated no substantial content of common essential oils in K.arvensis (R. Losa, personal communication). Further selective extraction and chromatography requires to be done to identify the active ingredient.

The magnitude of the proteolysis-inhibiting effect of monensin was greater than that of $K$. arvensis; the former, however, being a pure substance in contrast with a complex plant material. Extraction of the plant material will narrow down the spectrum of added compounds and avoid overlaps with nutritive effects of the plant samples. Testing of these extracts in the batch culture system should lead to a more distinctive impact on protein degradation.

A patent was filed (patent no. WO2005099729) for the application of $K$. arvensis and $P$. peltatum in ruminant nutrition.

\section{Conclusion}

Screening a targeted collection of 500 plants and plant extracts for effects on rumen microbial proteolysis revealed five samples that were particularly promising. Four were rich in tannins. These samples had no inhibitory influence on SCFA production, indicating that they may be less problematic in slowing fermentation than some other tannin-containing plants. Gas production was inhibited slightly, however, so further studies are required to determine the usefulness of these samples in vivo. The fifth sample, K. arvensis, had a different mode of action that seems to be particularly promising, in that it is different from any reported previously for inhibiting ruminal proteolysis and did not appear to cause any inhibition of fermentation. It is important now to elucidate the underlying mechanism of inhibition, its persistence in long-term culture experiments, the precise chemical nature of the active ingredient and to validate its nutritional usefulness in vivo. $K$. arvensis may eventually form the basis of alternative feed additives/ingredients that inhibit ruminal proteolysis and improve protein nutrition in ruminants.

\section{Acknowledgements}

The authors thank C. Apel, H. Baumgärtner and B. Fischer for excellent technical support and Dr E. Schlecht and Dr H. P. S. Makkar for critical reading of the manuscript. We are particularly grateful to Dr H. Steingaß, Institute of Animal Nutrition, University of Hohenheim, for access to cannulated cows. This work was part of the project RUMEN UP supported by the European Union commission (QLK5-CT-2001-00 992). We thank all partners of the consortium (H. Makkar, D. Beever, F. Mould, B. Morgan, K. Kliem, S. López, J. Gonzalez, C. Duffy, R. Losa, M. Frehner) for cooperation and valuable discussion. The Rowett Research Institute is funded by the Scottish Executive Environment and Rural Affairs Department.

\section{References}

Association of Official Analytical Chemists (1990) Official Methods of Analysis, 15th ed., Arlington, VA: AOAC. 
N. Selje et al.

Barry TN \& McNabb WC (1999) The implications of condensed tannins on the nutritive value of temperate forages fed to ruminants. Br J Nutr 81, 263-272.

Beynon RJ \& Salvesen G (1989) Commercially available protease inhibitors. In Proteolytic Enzymes, A Practical Approach, pp. 241-249 [RJ Benyon and JS Bond, editors]. Oxford: IRL Press.

Broderick GA \& Albrecht KA (1997) Crop quality and utilization: Ruminal in vitro degradation of protein in tannin-free ad tannincontaining forage legume species. Crop Sci 37, 1884-1891.

Callaway TR \& Russell JB (1999) Selection of a highly monensinresistant Prevotella bryantii subpopulation with altered outer membrane characteristics. Appl Environ Microbiol 65, 4753-4759.

Callaway TR, Russell JB \& Carneiro De Melo AMS (1997) The effect of nisin and monensin on ruminal fermentations in vitro. Curr Microbiol 35, 90-96.

Cardozo PW, Calsamiglia S, Ferret A \& Kamel C (2004) Effects of natural plant extracts on ruminal protein degradation and fermentation profiles in continuous culture. J Anim Sci 82, 3230-3236.

Chen M \& Wolin MJ (1979) Effect of monensin and lasalocid-sodium on the growth of methanogenic and rumen saccharolytic bacteria. Appl Environ Microbiol 38, 72-77.

Eugène M, Archimede H \& Sauvant D (2004) Quantitative metaanalysis on the effects of defaunation of the rumen on growth, intake and digestion in ruminants. Livest Prod Sci 85, 81-97.

Flåøyen A, di Menna ME, Wilkins AL, Sandvik M \& Berndt S (2004) Summer variation in the concentration of steroidal sapogenins in and the degree of fungal infection on Narthecium ossifragum plants from More og Romsdal County, Norway. Vet Res Commun 28, 225-234.

Hagerman AE \& Butler LG (1978) Protein precipitation method for the quantitative determination of tannins. J Agric Food Chem 26, 809-812.

Hervás G, Frutos P, Giráldez FJ, Mantecon AR \& Alvarez Del Pino MC (2003) Effect of different doses of quebracho tannins extract on rumen fermentation in ewes. Anim Feed Sci Technol 109, $65-78$.

Hervás G, Frutos P, Serrano E, Mantecon AR \& Giráldez FJ (2000) Effect of tannic acid on rumen degradation and intestinal digestion of treated soya bean meals in sheep. J Agricult Sci 135, 305-310.

Hervás G, Ramos G, Giráldez FJ \& Mantecon AR (2004) Effect of intraruminal administration of quebracho tannins on rumen degradation and total tract digestibility, faecal recovery and toxicity in sheep. J Anim Feed Sci 13, 113-122.

Hoeltershinken M, Plitt U, Tammen FC, Hoffmann P \& Scholz H (1997) Influence of mouldy grass on fermentation and thiamine metabolism in bovine rumen fluid (in-vitro). Deutsch Tierarztl Wochenschr 104, 17-22.

Hoffmann EM, Muetzel S \& Becker K (2002) A modified dot-blot method of protein determination applied in the tannin-protein precipitation assay to facilitate the evaluation of tannin activity in animal feeds. Br J Nutr 87, 421-426.

Ikedo S, Shimoyamada M \& Watanabe K (1996) Interaction between bovine serum albumin and saponin as studied by heat stability and protease digestion. J Agric Food Chem 44, 792-795.

Jalč D \& Lauková A (2002) Effect of nisin and monensin on rumen fermentation in the artificial rumen. Berl Munch Tierarztl Wochenschr 115, 6-10.

Jones BA, Muck RE \& Hatfield RD (1995) Red clover extracts inhibit legume proteolysis. J Sci Food Agric 67, 329-333.

Koroleff F (1976) Determination of ammonia. In Methods of Seawater Analysis, pp. 126-133 [K Grasshoff, editor]. Weinheim, Germany: Verlag Chemie.

Laemmli UK (1970) Cleavage of structural proteins during the assembly of the head of bacteriophage T4. Nature 227, 680-685.

Leng RA \& Nolan JV (1984) Nitrogen metabolism in the rumen. J Dairy Sci 67, 1072-1089.
McAllister TA, Bae HD, Yanke LJ, Cheng KJ \& Muir A (1994) Effect of condensed tannins from birdsfoot trefoil on endoglucanase activity and the digestion of cellulose filter paper by ruminal fungi. Can J Microbiol 40, 298-305.

McIntosh FM, Williams P, Losa R, Wallace RJ, Beever DA \& Newbold CJ (2003) Effects of essential oils on ruminal microorganisms and their protein metabolism. Appl Environ Microbiol 69, 5011-5014.

McMahon LR, McAllister TA, Berg BP, Majak W, Acharya SN, Popp JD, Coulman BE, Wang Y \& Cheng KJ (2000) A review of the effects of forage condensed tannins on ruminal fermentation and bloat in grazing cattle. Can J Plant Sci 80, 469-485.

Makkar HPS, Dawra RK \& Singh B (1988a) Changes in tannin content, polymerisation and protein precipitation capacity in oak (Quercus incana) leaves with maturity. J Sci Food Agricult 44, 301-307.

Makkar HPS, Singh B \& Dawra RK (1988b) Effect of tannin-rich leaves of oak (Quercus incana) on various microbial enzyme activities of the bovine rumen. Br J Nutr 60, 287-296.

Martínez TF, Moyano FJ, Barroso FG \& Alarcón FJ (2004) Ruminal degradation of tannin-treated legume meals. J Sci Food Agric 84, 1979-1987.

Mauricio RM, Mould FL, Dhanoa MS, Owen E, Channa KS \& Theodorou MK (1999) A semi-automated in vitro gas production technique for ruminant feedstuff evaluation. Anim Feed Sci Technol 79, 321-330.

Michelet-Doreau B \& Ould-Bah MY (1992) In vitro and in sacco methods for the estimation of dietary nitrogen degradability in the rumen: a review. Anim Feed Sci Technol 40, 57-86.

Molan AL, Attwood GT, Min WK \& McNabb WC (2001) The effect of condensed tannins from Lotus pedunculatus and Lotus corniculatus on the growth of proteolytic rumen bacteria in vitro and their possible mode of action. Can J Microbiol 47, 626-633.

National Research Council (2001) Nutrient Requirements of Dairy Cattle, 7th ed. Washington, DC: National Academies Press.

Neuhoff V, Stamm R \& Eibel H (1985) Clear background and highly sensitive protein staining with Coomassie Brilliant Blue dyes in polyacrylamide gels: A systematic analysis. Electrophoresis 6, 427-448.

Newbold CJ, Wallace RJ \& McKain N (1990) Effect of the ionophore tetronasin, on nitrogen metabolism of rumen microorganisms in vitro. J Anim Sci 68, 1103-1109.

Phipps RH, Wilkinson JID, Jonker LJ, Tarrant M, Jones AK \& Hodge A (2000) Effect of monensin on milk production of holstein-Friesian dairy cows. J Dairy Sci 83, 2789-2794.

Poncet C \& Rémond D (2002) Rumen digestion and intestinal nutrient flows in sheep consuming pea seeds: The effect of extrusion or chestnut tannin addition. Anim Res 51, 201-216.

Potter SM, Jiminez-Flores R, Pollak JA, Lone TA \& Berber-Jiminez MD (1993) Protein-saponin interaction and its influence on blood lipids. J Agric Food Chem 41, 1287-1291.

Ramanzin M, Bailoni L, Schiavon S \& Bittante G (1997) Effect of monensin on milk production and efficiency of dairy cows fed two diets differing in forage to concentrate ratios. J Dairy Sci 80, 1136-1142.

Reed JD, McDowell RE, Van Soest PJ \& Horvath PJ (1982) Condensed tannins, a factor limiting the use of cassava forage. J Sci Food Agric 33, 213-220.

Santos FAP, Santos JEP, Theurer CB \& Huber JT (1998) Effects of rumen-undegradable protein on dairy cow performance: A 12-year literature review. J Dairy Sci 81, 3182-3213.

Schelling GT (1984) Monensin mode of action in the rumen. J Anim Sci 58, 1518-1527.

Schwab CG, Tylutki TP, Ordway RS, Sheaffer C \& Stern MD (2003) Characterization of proteins in feeds. J Dairy Sci 86, E88-E103. 
Shimoyamada M, Ikedo S, Ootsubo R \& Watanabe K (1998) Effects of soybean saponins on chymotryptic hydrolyses of soybean proteins. J Agric Food Chem 46, 4793-4797.

Silanikove N, Perevolotsky A \& Provenza FD (2001) Use of tannin-binding chemicals to assay for tannins and their negative postingestive effects in ruminants. Anim Feed Sci Technol 91, 69-81.

Śliwiński BJ, Kreuzer M, Wettstein HR \& Machmüller A (2002) Rumen fermentation and nitrogen balance of lambs fed diets containing plant extracts rich in tannins and saponins, and associated emissions of nitrogen and methane. Arch Anim Nutr 56, 379-392.

Tanner GJ, Moore AE \& Larkin PJ (1994) Proanthocyanidins inhibit hydrolysis of leaf proteins by rumen microflora in vitro. Br J Nutr 71, 947-958.

Van Nevel CJ \& Demeyer DI (1977) Effect of monensin on rumen metabolism in vitro. Appl Environ Microbiol 34, 251-257.

Van Soest PJ, Robertson JB \& Lewis BA (1991) Symposium: carbohydrate methodology, metabolism, and nutritional implications in dairy cattle. Methods for dietary fiber, neutral detergent fiber and non starch polysaccharides in relation to animal nutrition. J Dairy Sci 74, 3583-3597.
Waghorn GC, Shelton ID, McNabb WC \& McCutcheon SH (1994) Effects of condensed tannins in Lotus pedunculatus on its nutritive value for sheep. 2. Nitrogenous aspects. J Agric Sci 123, 109-119.

Waghorn GC, Ulyatt MJ, Johns A \& Fisher MT (1987) The effect of condensed tannins on the site of digestion of amino acids and other nutrients in sheep fed Lotus corniculatus. Br J Nutr 57, 115-126.

Wallace RJ (1983) Hydrolysis of ${ }^{14} \mathrm{C}$-labelled proteins by rumen micro-organisms and by proteolytic enzymes prepared from rumen bacteria. Br J Nutr 50, 345-355.

Wallace RJ (2004) Antimicrobial properties of plant secondary metabolites. Proc Nutr Soc 63, 621-629.

Wina E, Muetzel S \& Becker K (2005) The impact of saponins or saponin-containing plant materials on ruminant production - a review. J Agric Food Chem 53, 8093-8105.

Wink M (1999) Introduction: biochemistry, role and biotechnology of secondary metabolites. In Functions of Plant Secondary Metabolites and Their Exploitation in Biotechnology, pp. 1-16 [M Wink, editor]. Sheffield, UK: Sheffield Academic Press.

Yang CM \& Russell JB (1993) The effect of monensin supplementation on ruminal ammonia accumulation in vivo and the numbers of amino acid-fermenting bacteria. J Anim Sci 71, $3470-3476$. 